\title{
The role of extracorporeal shock wave lithotripsy in the treatment of chronic pancreatitis
}

\author{
D. Geusens, H. van Malenstein \\ Department of Gastroenterology and Hepatology, University Hospitals Leuven, Belgium.
}

\begin{abstract}
Pain is the most frequent symptom in chronic pancreatitis (CP) and has an important impact on quality of life. One of its major pathophysiological mechanisms is ductal hypertension, caused by main pancreatic duct stones and/or strictures. In this article, we focus on extracorporeal shock wave lithotripsy (ESWL) as a treatment for main pancreatic duct stones, which have been reported in $>\mathbf{5 0} \%$ of CP patients. ESWL uses acoustic pulses to generate compressive stress on the stones, resulting in their gradual fragmentation. In patients with radiopaque obstructive main pancreatic duct (MPD) stones larger than $5 \mathrm{~mm}$, located in the pancreas head or body, ESWL improves ductal clearance, thereby relieving pain and improving quality of life. In case of insufficient ductal clearance or the presence of an MPD stricture, ESWL can be followed by endoscopic retrograde cholangiopancreatography (ERCP) to increase success rate. Alternatively, direct pancreaticoscopy with intracorporeal lithotripsy or surgery can be performed (Acta gastroenterol. belg., 2021, 84, 620-626).
\end{abstract}

Keywords: calcifications, chronic pancreatitis, pain, lithotripsy, ESWL.

\section{Introduction}

Chronic pancreatitis (CP) is a progressive, inflammatory disorder resulting in structural damage and fibrosis, which can ultimately lead to pancreatic exocrine and endocrine dysfunction $(1,2)$.

Alcohol is considered the most common etiologic factor, accounting for $44-65 \%$ of the cases. Other risk factors for chronic pancreatitis are included in the TIGAR-O classification: toxic-metabolic, idiopathic, genetic, autoimmune, recurrent and severe acute pancreatitis and obstructive etiologic factors, such as pancreas divisum or rarely a bifurcation of the pancreatic duct (3-6).

Abdominal pain, which might be constant in nature or occur in flares (7), is the most disabling symptom of chronic pancreatitis, especially in patients with alcoholic etiology (8-10). The complex underlying pathophysiological pain mechanisms can be devided into three components $(1,9)$. First, multiple neuropathic alterations take place, including an increase in size and number of intrapancreatic nerves, perineural inflammation and visceral and central sensitisation $(11,12)$. Second, pancreas tissue inflammation, fibrosis and calcifications result in parenchymal hypertension and ischaemia (1). The third and probably easiest mechanism to target is ductal hypertension, which is caused by the formation of stones and/or strictures in the main pancreatic duct $(13,14)$.
The general management of chronic pancreatitis includes life style changes such as abstinence from smoking and alcohol, analgesics using the "pain relief ladder" and treatment of pancreatic exocrine and endocrine insufficiency $(3,8)$. However, one of the cornerstones in the treatment of pain in CP is relieving ductal hypertension, which can be achieved by ESWL, endoscopic (ERCP) or surgical methods (15-17).

In this article we review ESWL as a treatment for pancreatic ductal stones, its indications, efficacy and the rationale for combination therapy with ERCP.

\section{Pancreatic ductal stones}

Pancreatic stones are common, direct sequelae of chronic pancreatitis. The vast majority appears as calcified stones, but they can also project as radiolucent protein plugs. The latter may or may not become calcified during the further course of disease (18). Pancreatic calculi are estimated to occur in about $50 \%$ of patients, particularly in those with alcohol-induced CP $(15,18)$. Their prevalence even increases with time and reaches up to approximately $100 \%$ at 14 years after disease onset $(16,18)$.

Calcifications in $\mathrm{CP}$ are due to a supersaturation of the pancreatic fluid with calcium carbonate, which deposits in multiple layers over an amorphous inner nidus $(1,17)$.

Pancreatic calculi are classified based upon type (radiopaque, radiolucent or mixed) and number (single or multiple stones). Furthermore, the location in relation to the duct (main pancreatic duct, side branches or pancreatic parenchyma) and the region of the pancreas (head, body or tail) are relevant in their therapeutic approach (17).

\section{Treatment of pancreatic ductal stones - who to select for ESWL?}

ERCP is recommended as first line therapy for small $(<5 \mathrm{~mm})$ or radiolucent main pancreatic duct stones, using pancreatic sphincterotomy with basket or balloon

Correspondence to : H. van Malenstein, Dienst gastro-enterologie en hepatologie, Herestraat 49, 3000 Leuven, Belgium

E-mail : hannah.vanmalenstein@uzleuven.be

Submission date : 10/12/2020

Acceptance date : 21/03/2021 
extraction, and for ductal stenting in the presence of a dominant main pancreatic duct stricture $(8,18)$.

In uncomplicated $\mathrm{CP}$ with large $(>5 \mathrm{~mm}) \mathrm{MPD}$ calculi, ESWL is considered the gold standard treatment. Patients with few radiopaque obstructive calcifications, wich are ideally located in the head or body of the pancreas, and secondary upstream ductal dilation are the best candidates $(3,8,17)$. The use of ESWL is not recommended in patients with multifocal strictures, extensive calculi and/or pancreatic tail calculi, the last due to the risk of collateral damage to the spleen. Other contra-indications to ESWL include pregnancy, coagulopathy and the presence of a head mass under evaluation. In case of difficult visualisation, especially with radiolucent stones, prior endoscopic placement of a pancreatic duct stent or naso-pancreatic tube for the instillation of contrast may help target the shock waves at the time of the ESWL procedure $(16,17)$.

Surgical options consist of drainage (in ductal obstruction), resection (in inflammatory masses or $\mathrm{CP}$ restricted to one part of the pancreas) or combined procedures. A detailed discussion of the surgical techniques, however, is beyond the scope of this article. Current evidence suggests that early surgical intervention within the first 2-3 years after diagnosis or symptom onset, may result in better pain control $(8$, $15,19)$. Several randomised controlled trials compared the effects of surgical and endoscopic interventions in the management of painful obstructive CP (20-23). All suggested superiority of surgery in treating pain, though most of these studies had important shortcomings, both in terms of methodology and the endoscopic techniques used. Endotherapy and surgery should probably be considered as complimentary rather than competitive strategies. Patients with few uncomplicated pancreatic duct stones or strictures, limited to the head of the pancreas, will benefit from endoscopy/ESWL as first line therapy. For patients with an inflammatory head mass or multiple strictures or calculi, surgery might be a better option $(17,19)$. In any case, short-term follow-up after endoscopy and, if indicated, early referral to surgery is essential (23).

\section{The ESWL procedure}

ESWL was first introduced in 1980 for the desintegration of renal calculi (24), whereas the earliest description of its use in calcified chronic pancreatitis dates from 1987 (25).

In ESWL shock waves are focussed on ductal stones, which generates compressive stress on their outer surface, resulting in a gradual fragmentation. All lithotripters share four basic components: a shock wave generator, a focusing system, a coupling mechanism and a stone localization unit. There are three sources available for generating shock waves, where each has its own focusing system. The original method is electrohydraulic, meaning that the shock wave is produced by an electric spark-gap located at the base of a water-filled container, which directs the acoustic wave from an ellipsoidal reflector towards the stone at the focal point $(26,27)$. Second, piezoelectric shock waves are generated by the stimulation of ceramics via high-frequency, high-voltage energy pulses. The motion of these piezoceramic elements, which are arranged within a hemispherical disc, creates ultrasonic vibrations, resulting in the production of a shock wave directed to the focal point $(26,27)$. Finally, in electromagnetic devices, a high voltage is applied to an electromagnetic coil, which induces high-frequency vibration in an adjacent metallic membrane. This highpressure wave is transformed into a shock wave and focused by an acoustic lens $(26,27)$. At interfaces with different densities, such as the skin surface, a shock wave loses energy. Therefore water is used as a coupling system, as this has a density similar to that of soft tissue. In the first lithotripters the patient was placed in a water bath, whereas second and third generation machines use an enclosed water cushion to provide air-free contact with the patient's skin $(27,28)$. Finally, imaging systems are used to localize the stone as well as to track the progress of treatment and consist of either fluoroscopy or ultrasonography $(26,27,29)$. The use of the former results in the best fragmentation of pancreatic stones (26). Ultrasonography has the advantage of preventing exposure to ionizing radiation, however it may have low precision due to interposed air-filled bowels. Some third generation lithotripters combine both imaging systems in the same machine (26).

Shock waves generated by piezoelectric or electromagnetic systems generally have a smaller highintensity focal zone compared with electrohydraulic lithotripters. Although this results in less tissue damage and less pain during the procedure, respiration may cause the stone to move out of the target zone, thereby leading to higher retreatment rates (26). There were no significant differences between electromagnetic and electrohydraulic systems regarding clearance of endoscopically unretrieveble pancreatic duct stones, however a lower number of shock waves per patient was administered in the electrohydraulic group, due to a greater power (26).

The optimal frequency of shock wave administration seems to be 90 shock waves per minute. Faster rates are associated with lower succes rates of ESWL in urolithiasis, especially in large stones (greater than 10 $\mathrm{mm}$ ), whereas slower rates obviously increase the total procedure time (30).

If there is insufficient fragmentation, the procedure can be repeated, with the total number of ESWL sessions per patient ranging from 1 to 12 in reported series (31$35)$. In more than half of these patients only one ESWL procedure was performed $(55-60 \%)$ but the mean number of sessions varied around 2-3 (13,31-37) (Table 1). How the technical success of ESWL was determined and whether there was a predefined maximum number of sessions varied greatly between the studies, highlighting 
Table 1. - Number of ESWL sessions

\begin{tabular}{|c|c|c|c|c|c|}
\hline Author, year & Study design & Patients, n (m/f) & $\begin{array}{l}\text { Minimum } \\
\text { ESWL } \\
\text { sessions }\end{array}$ & $\begin{array}{l}\text { Maximum ESWL } \\
\text { sessions }\end{array}$ & Median/Mean ESWL sessions \\
\hline $\begin{array}{l}\text { Korpela et al, } \\
2016(31)\end{array}$ & Retrospective & $83(59 / 24)$ & 1 & 4 & mean: 1 \\
\hline Li et al, 2016 (32) & Prospective & $\begin{array}{c}849 \text { (603/246), PPC: } 59(51 / 8), \\
\text { Non-PPC: } 790(552 / 238)\end{array}$ & 1 & PPC: 5, Non-PPC: 12 & median: 2 \\
\hline $\begin{array}{l}\text { Tandan et al, } 2010 \\
\text { (33) }\end{array}$ & Prospective & $1006(663 / 343)$ & 1 & 6 & NR \\
\hline $\begin{array}{l}\text { Dumonceau et al, } \\
2007(34)\end{array}$ & $\mathrm{RCT}$ & $\begin{array}{l}55 \text { (43/12), ESWL alone: } 26(22 / 4) \text {, } \\
\text { ESWL and endoscopy: } 29(21 / 8)\end{array}$ & 1 & $\begin{array}{l}\text { ESWL alone: } 3, \text { ESWL } \\
\text { and endoscopy: } 4\end{array}$ & mean: 2 \\
\hline $\begin{array}{l}\text { Tadenuma et al, } \\
2005 \text { (37) }\end{array}$ & Retrospective & $117(85 / 32)$ & NR & NR & mean: 5.8 \\
\hline $\begin{array}{l}\text { Delhaye et al, } \\
2004(36)\end{array}$ & Prospective & $56(46 / 10)$ & NR & NR & \begin{tabular}{|c|} 
Clinical success group: mean \\
0.7 , Clinical failure group: mean \\
1.5 \\
\end{tabular} \\
\hline $\begin{array}{l}\text { Farnbacher et al, } \\
2002 \text { (13) }\end{array}$ & Retrospective & $114(\mathrm{NR})$ & NR & NR & mean: 2,5 \\
\hline $\begin{array}{l}\text { Karasawa et al, } \\
2002(35)\end{array}$ & Retrospective & $24(19 / 5)$ & 1 & 12 & mean: 3.6 \\
\hline
\end{tabular}

ESWL, extracorporeal shock wave lithotripsy; NR, not reported; PPC, pancreatic pseudocyst; RCT, randomised controlled trial

Table 2. - Comparative results

\begin{tabular}{|c|c|c|c|c|c|}
\hline Author, year & Study design & Patients, $\mathbf{n}(\mathrm{m} / \mathrm{f})$ & $\begin{array}{c}\text { Post-ESWL ERCP, } \\
\text { n/N (\%) }\end{array}$ & $\begin{array}{l}\text { Complete ductal } \\
\text { clearance, } n / \mathbf{N}(\%)\end{array}$ & $\begin{array}{l}\text { Outcome in terms of pain } \\
\text { relief, } n / N(\%)\end{array}$ \\
\hline Korpela et al, 2016 (31) & Retrospective & $83(59 / 24)$ & $83 / 83(100 \%)$ & $69 / 83(83 \%)$ & $\begin{array}{c}\text { Complete or partial pain relief: } \\
74 / 83(89 \%)\end{array}$ \\
\hline Li et al, 2016 (32) & Prospective & $\begin{array}{c}849 \text { (603/246), PPC: } 59 \\
\text { (51/8), Non-PPC: } 790 \\
\text { (552/238) }\end{array}$ & $\begin{array}{l}\text { PPC: } 58 / 59(98 \%) \\
\text { Non-PPC: NR }\end{array}$ & $\begin{array}{c}\text { 696/849 (82\%), PPC: } \\
\text { 39/58 (67\%), Non- } \\
\text { PPC: } 657 / 790(83 \%)\end{array}$ & $\begin{array}{l}\text { Complete pain relief in PPC: } \\
35 / 55(64 \%) \text {, Partial pain } \\
\text { relief in PPC: } 14 / 55(26 \%)\end{array}$ \\
\hline Vaysse et al, 2016 (54) & Retrospective & $146(96 / 50)$ & $91 / 132(69 \%)$ & $75 / 132(57 \%)$ & $\begin{array}{c}\text { Clinical success }{ }^{1}: 100 / 132 \\
(76 \%)\end{array}$ \\
\hline Suzuki et al, 2013 (52) & Retrospective & $479(\mathrm{NR})$ & $255 / 479(53 \%)$ & $356 / 479(74 \%)$ & Pain relief: 435/479 (91\%) \\
\hline Milovic et al, 2011 (48) & Prospective & $32(24 / 8)$ & $32 / 32(100 \%)$ & $13 / 32(41 \%)$ & $\begin{array}{l}\text { Complete pain relief: } 17 / 32 \\
(53 \%)\end{array}$ \\
\hline Merrill et al, 2011 (57) & Retrospective & $30(20 / 10)$ & $30 / 30(100 \%)$ & $27 / 30(90 \%)$ & NR \\
\hline Tandan et al, 2010 (33) & Prospective & $1006(663 / 343)$ & $1006 / 1006(100 \%)$ & $762 / 1006(76 \%)$ & $\begin{array}{c}\text { Significant relief of pain with } \\
\text { decrease in analgesic use: } \\
711 / 846(84 \%)\end{array}$ \\
\hline $\begin{array}{l}\text { Dumonceau et al, } 2007 \\
(34)\end{array}$ & RCT & $\begin{array}{c}55(43 / 12), \text { ESWL } \\
\text { alone: } 26(22 / 4), \\
\text { ESWL and endoscopy: } \\
29(21 / 8) \\
\end{array}$ & $29 / 55(53 \%)$ & NR & $\begin{array}{l}\text { Pain relapse at } 2 \text { year } \\
\text { follow up in ESWL alone: } \\
\text { 10/26 (38\%), in ESWL and } \\
\text { endoscopy: } 13 / 29(45 \%)\end{array}$ \\
\hline Tadenuma et al, 2005 (37) & Retrospective & $117(85 / 32)$ & $65 / 115(56 \%)$ & $65 / 115(56 \%)$ & $\begin{array}{l}\text { Significant relief of pain at } 1 \\
\text { year follow up: } 49 / 70(70 \%)\end{array}$ \\
\hline Inui et al, 2005 (51) & Retrospective & $555(465 / 90)$ & $237 / 555(43 \%)$ & $403 / 555(73 \%)$ & Pain relief: 428/470 (91\%) \\
\hline Delhaye et al, 2004 (36) & Prospective & $56(46 / 10)$ & $56 / 56(100 \%)$ & $27 / 56(48 \%)$ & NR \\
\hline $\begin{array}{l}\text { Farnbacher et al, } 2002 \\
(13)\end{array}$ & Retrospective & 114 (NR) & NR & $39 / 114(34 \%)$ & NR \\
\hline Karasawa et al, 2002 (35) & Retrospective & $24(19 / 5)$ & $14 / 24(58 \%)$ & $13 / 24(54 \%)$ & $\begin{array}{c}\text { Relief of abdominal symptoms } \\
\text { at } 1 \text { year follow up: } 11 / 24 \\
(46 \%)\end{array}$ \\
\hline Brand et al, 2000 (50) & Prospective & $48(35 / 13)$ & $48 / 48(100 \%)$ & $21 / 48(44 \%)$ & $\begin{array}{c}\text { Complete pain relief: } 17 / 38 \\
(45 \%), \text { Partial pain relief: } \\
14 / 38(37 \%) \\
\end{array}$ \\
\hline
\end{tabular}

ERCP, endoscopic retrograde cholangiopancreatography; ESWL, extracorporeal shock wave lithotripsy; NR, not reported; PPC, pancreatic pseudocyst; RCT, randomised controlled trial. ${ }^{1}$ Resolution of pain, no analgesic treatment, no acute pancreatitis and no surgical treatment for chronic pancreatitis 6 months after the ESWL.

the need for a standardised method to evaluate the efficacy of each ESWL session. In clinical practice, ESWL is often combined with ERCP and the ability to extract MPD stones is hereby used to assess the efficacy of ESWL. Alternatively, evaluation of fragmentation by
CT scan or assesment of the reduction of MPD dilation could be markers of sufficient drainage.

ESWL for pancreas lithiasis is mostly performed by urologists. Jaben et al showed that a transition to gastroenterologist-directed ESWL resulted in a higher 
mean number of shocks per ESWL session and improved ductal clearance, with more patients undergoing samesession ERCP (38).

ESWL can be carried out under moderate sedation, epidural anesthesia or general anesthesia. Epidural anesthesia seems to provide better patient tolerance than moderate sedation and by reducing patient movements, it facilitates targeting and fragmentation of the stones $(39,40)$. In patients undergoing ESWL and ERCP consecutively, general anesthesia can be used (26).

Finally, data on post-ESWL pancreatitis prophylaxis are lacking because in most studies ESWL and ERCP were consistently combined.

\section{Efficacy and complications of ESWL}

Three meta-analyses studied the efficacy of ESWL in the treatment of calcified CP (41-43). In one metaanalysis by Moole et al, comprising data of 27 studies including 3189 patients, a complete pain relief and an improved quality of life were reported in $52,7 \%$ and $88,2 \%$ of pooled patients, respectively. Ductal clearance, defined as $>90 \%$ clearance of the MPD stones, was complete in $70,7 \%$ of pooled patients (41). The most recent meta-analysis, by Van Huijgevoort et al, reported similar results with a complete ductal clearance in $69,8 \%$ and a complete pain relief in $64,2 \%$ of pooled patients (43). No conclusions were drawn about the effect of ESWL on exocrine and endocrine dysfunction, due to the heterogeneity of the different studies $(41,43)$. In addition, several trials reported a long-term clinical succes of ESWL, both in terms of sustained pain relief as well as avoidance of surgery $(31,36,37,44)$.

Comparative results of reported series are listed in Table 2. Factors associated with a higher rate of ductal clearance after ESWL are solitary stones, stones located in the pancreatic head, pancreatic stenting prior to ESWL and administration of secretin during ESWL $(13,18,31,45)$.

ESWL is generally considered a safe procedure. In a prospective study with 634 patients major complications were classified into five groups, including post-ESWL pancreatitis, bleeding, infection, steinstrasse (acute stone incarceration in the papilla) and perforation (46). These complications and transient adverse events, such as skin erythema, mild tenderness of the region in contact with the shockwave head, asymptomatic hyperamylasemia, hematuria and gastrointestinal mucosal injury, were detected in $6,7 \%$ and $21,2 \%$ of the procedures, respectively (46). Other rare complications that have been described following ESWL include splenic rupture, pancreaticobiliary fistula, pancreatic fluid collections, perirenal hematoma, biliary obstruction, bowel perforation and liver trauma $(17,41,43,46)$. Complication frequencies are listed in Table 3. Given that ESWL is complicated with post-procedural pancreatitis in around $4 \%$ of the patients (41), one could argue that adequate intravenous hydration and NSAID prophylaxis may be beneficial, analogous to post-ERCP pancreatitis prophylaxis.
Table 3. - Complication frequencies

\begin{tabular}{|l|c|}
\hline Complication & Frequency (43, 46) \\
\hline Pancreatitis & $4 \%$ \\
\hline Infection & $1.4 \%$ \\
\hline Bleeding & $0.3 \%$ \\
\hline Steinstrasse & $0.4 \%$ \\
\hline Perforation & $0.3 \%$ \\
\hline Pancreatico-biliary fistula & $0.1 \%$ \\
\hline $\begin{array}{l}\text { Other: splenic rupture, pancreatic fluid } \\
\text { collection, perirenal hematoma, biliary } \\
\text { obstruction, bowel perforation, liver trauma }\end{array}$ & Case reports \\
\hline
\end{tabular}

\section{Combination of ESWL and ERCP}

As mentioned before, in most clinical studies it was common practice to perform an ERCP, with stone extraction and pancreatic stenting when indicated, after ESWL $(13,31,36,37,44,47-50)$. In terms of ductal clearance, small studies showed a benefit of a complementary ERCP procedure, although to a varying degree $(51,52)$. Since a complete ductal clearance results in better pain relief, both on the short and the long term, combination therapy might be the preferred strategy $(13,37)$.

By contrast, Ohara et al suggested that ESWL alone is sufficient to treat MPD calculi (53). Only two studies, one randomised controlled trial and one retrospective clinical study, provided a head-to-head comparison between ESWL alone and a combination of ESWL and ERCP $(33,54)$. Both showed that ESWL is a safe and effective treatment for patients with painful calcified CP. However, systematic combination with therapeutic ERCP added to the cost of patient care without any additional benefit in pain control.

A large cohort of patients with $\mathrm{CP}$ and pain showed that ductal hypertension was due to calcifications in $18 \%$, strictures in $47 \%$ and a combination of both in $32 \%$ (55). The presence of an MPD stricture is associated with a higher risk of long-term pain relapse (37) and requires interventional ERCP with ductal stenting $(8,18,56)$. Therefore, in clinical practice, the combined presence of strictures and calculi often necessitates the use of both ERCP and ESWL. This is also reflected in the current European Society of Gastrointestinal Endoscopy (ESGE) guidelines, which recommend restricting the use of endoscopic therapy after ESWL to patients without spontaneous clearance of pancreatic stones after adequate fragmentation by ESWL and to patients with MPD strictures (18). A flowchart for the choice of therapy is given in Figure 1.

Another matter of debate is the timing of ERCP after ESWL. Some data suggest that if additional ERCP is needed, it should be performed at least two days after ESWL, because of the possible presence of reactive edema in the MPD or surrouding tissues (57). Remarkably, in the randomised trial studying ESWL versus ESWL with $\mathrm{ERCP}$, the endoscopic procedure was done immediately after the last ESWL session (33). 


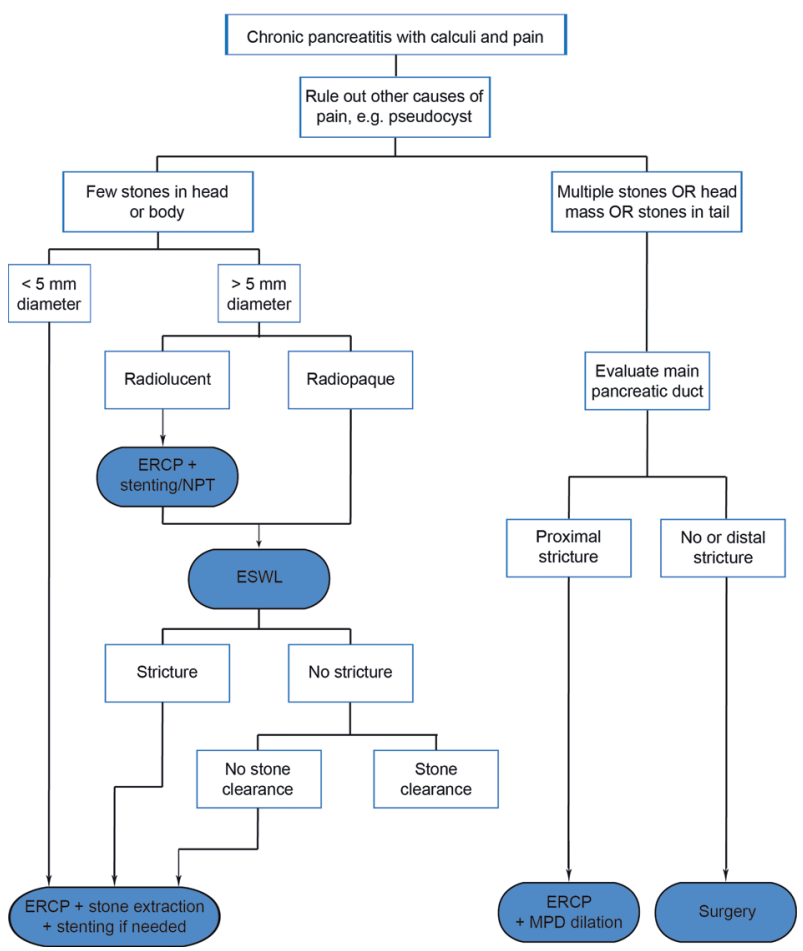

Figure 1. - Flowchart choice of therapy

ERCP, endoscopic retrograde cholangiopancreatography; ESWL, extracorporeal shock wave lithotripsy; MPD, main pancreatic duct; NPT, naso-pancreatic tube.

\section{Conclusion and future prospects}

The current rationale for treating pain in chronic calcified pancreatitis is the relief of ductal hypertension. In this article, we focussed on ESWL as a treatment for MPD stones. Studies show that ESWL is an effective therapy in $\mathrm{CP}$ patients with large ductal stones in the pancreatic head and neck. In case of insufficient ductal clearance or strictures, additional ERCP improves outcome. In contrast, surgery is mostly reserved for patients failing endoscopic therapy or patients with suspected malignancy, although there are increasing data that early surgical interventions may lead to better pain control. To establish the position of early surgery as well as the position and timing of combination therapy (ESWL and ERCP) in the treatment of painful pancreatic duct calculi, we are in need of more prospective, randomised and controlled studies. Furthermore, the assessment of the efficacy of ESWL should be standardised.

Other strategies have been proposed to improve pain management and ductal clearance. First, the quality of peroral pancreaticoscopy has improved substantially. Data of its use with intracorporeal (electrohydraulic or laser) lithotripsy are sparse, but the first available results are promissing in terms of pain relief and ductal clearance (58). For now, this technique could provide a solution for stones that were not fragmented after adequately performed ESWL $(17,18)$. However, the main pancreatic duct must be sufficiently dilated to allow passage of the pancreaticoscope.
Another approach to optimise ductal clearance is intravenous administration of secretin during ESWL, as suggested by Choi et al (45). Analogous to the use of diuretics in ESWL for ureteral stones, secretin stimulates pancreatic fluid secretion and results in a distention of the pancreatic duct. This creates a fluid-filled space around the stones, which enhances the efficacy of the shock waves. In addition, it might expedite flushing out stone fragments. Unfortunately, complication rates were not reported in this study.

Finally, the current treatments do not take into account our advances in the understanding of pain mechanisms in chronic pancreatitis (19). In particular, the neuroplastic changes and the mechanism of central sensitisation could serve as therapeutic targets in the near future.

\section{Conflict of interest}

None

\section{References}

1. BRAGANZA J. M., LEE S. H., MCCLOY R. F., MCMAHON M. J. Chronic pancreatitis. Lancet, 2011, 377 : 1184-1197.

2. WHITCOMB D. C., FRULLONI L., GARG P., GREER J. B., SCHNEIDER A., YADAV D. et al. Chronic pancreatitis: An international draft consensus proposal for a new mechanistic definition. Pancreatology, 2016, 16 : 218224.

3. DELHAYE M., VAN STEENBERGEN W., CESMELI E., PELCKMANS P., PUTZEYS V., ROEYEN G. et al. Belgian consensus on chronic pancreatitis in adults and children: statements on diagnosis and nutritional, medical, and surgical treatment. Acta Gastroenterol. Belg., 2014, 77 : 47-65.

4. CONWELL D. L., LEE L. S., YADAV D., LONGNECKER D. S., MILLER F. H., MORTELE K. J. et al. American Pancreatic Association Practice Guidelines in Chronic Pancreatitis: evidence-based report on diagnostic guidelines. Pancreas, 2014, 43 : 1143-1162.

5. KROTT L., DE WULF D., DE CONINCK S., DEGROOTE H. Bifurcation of the main pancreatic duct in the body of the pancreas. Two case reports and literature study of a rare anatomical variant of the pancreatic duct. Acta Gastroenterol. Belg., 2020, 83 : 639-642.

6. GUPTA P., VERMA N., SAMANTA J., MANDAVDHARE H., SHARMA V., KANT SINHA S. et al. Variability of contrast enhancement of pancreas on computed tomography in patients with acute pancreatitis and isolated extrapancreatic necrosis. Acta Gastroenterol. Belg., 2020, 83 : 593-597.

7. AMMANN R. W. The natural history of alcoholic chronic pancreatitis. Intern. Med., 2001, $40:$ 368-375.

8. DREWES A. M., BOUWENSE S. A. W., CAMPBELL C. M., CEYHAN G. O., DELHAYE M., DEMIR I. E. et al. Guidelines for the understanding and management of pain in chronic pancreatitis. Pancreatology, 2017, 17 : 720731.

9. LIEB J. G., 2ND, FORSMARK C. E. Review article: pain and chronic pancreatitis. Aliment. Pharmacol. Ther., 2009, 29 : 706-719.

10. MULLADY D. K., YADAV D., AMANN S. T., O'CONNELL M. R., BARMADA M. M., ELTA G. H. et al. Type of pain, pain-associated complications, quality of life, disability and resource utilisation in chronic pancreatitis: a prospective cohort study. Gut, 2011, 60 : 77-84.

11. DEMIR I. E., FRIESS H., CEYHAN G. O. Neural plasticity in pancreatitis and pancreatic cancer. Nat. Rev. Gastroenterol. Hepatol., 2015, 12 : 649-659.

12. CEYHAN G. O., BERGMANN F., KADIHASANOGLU M., ALTINTAS B., DEMIR I. E., HINZ U. et al. Pancreatic neuropathy and neuropathic pain--a comprehensive pathomorphological study of 546 cases. Gastroenterology, 2009, 136 : 177-186.e171

13. FARNBACHER M. J., SCHOEN C., RABENSTEIN T., BENNINGER J., HAHN E. G., SCHNEIDER H. T. Pancreatic duct stones in chronic pancreatitis: criteria for treatment intensity and success. Gastrointest. Endosc., 2002, $56: 501-506$.

14. EBBEHØJ N., BORLY L., BÜLOW J., RASMUSSEN S. G., MADSEN P. Evaluation of pancreatic tissue fluid pressure and pain in chronic pancreatitis. A longitudinal study. Scand. J. Gastroenterol., 1990, 25 : 462-466. 
15. LÖHR J. M., DOMINGUEZ-MUNOZ E., ROSENDAHL J., BESSELINK M., MAYERLE J., LERCH M. M. et al. United European Gastroenterology evidence-based guidelines for the diagnosis and therapy of chronic pancreatitis (HaPanEU). United European Gastroenterol. J., 2017, 5 : 153 199.

16. SHARZEHI K. Management of Pancreatic Duct Stones. Curr. Gastroenterol. Rep., 2019, $21: 63$.

17. TANDAN M., TALUKDAR R., REDDY D. N. Management of Pancreatic Calculi: An Update. Gut Liver, 2016, $10: 873-880$

18. DUMONCEAU J. M., DELHAYE M., TRINGALI A., ARVANITAKIS M., SANCHEZ-YAGUE A., VAYSSE T. et al. Endoscopic treatment of chronic pancreatitis: European Society of Gastrointestinal Endoscopy (ESGE) Guideline - Updated August 2018. Endoscopy, 2019, 51 : 179-193.

19. DREWES A. M., KEMPENEERS M. A., ANDERSEN D. K., ARENDTNIELSEN L., BESSELINK M. G., BOERMEESTER M. A. et al. Controversies on the endoscopic and surgical management of pain in patients with chronic pancreatitis: pros and cons! Gut, 2019, 68 : 1343-1351.

20. CAHEN D. L., GOUMA D. J., NIO Y., RAUWS E. A., BOERMEESTER M A., BUSCH O. R. et al. Endoscopic versus surgical drainage of the pancreatic duct in chronic pancreatitis. N. Engl. J. Med., 2007, 356 : 676-684.

21. CAHEN D. L., GOUMA D. J., LARAMÉE P., NIO Y., RAUWS E. A., BOERMEESTER M. A. et al. Long-term outcomes of endoscopic vs surgical drainage of the pancreatic duct in patients with chronic pancreatitis. Gastroenterology, 2011, $141:$ 1690-1695.

22. DÍTE P., RUZICKA M., ZBORIL V., NOVOTNÝ I. A prospective, randomized trial comparing endoscopic and surgical therapy for chronic pancreatitis. Endoscopy, 2003, 35 : 553-558

23. ISSA Y., KEMPENEERS M. A., BRUNO M. J., FOCKENS P., POLEY J. W., AHMED ALI U. et al. Effect of Early Surgery vs Endoscopy-First Approach on Pain in Patients With Chronic Pancreatitis: The ESCAPE Randomized Clinical Trial. Jama., 2020, $323: 237-247$.

24. CHAUSSY C., BRENDEL W., SCHMIEDT E. Extracorporeally induced destruction of kidney stones by shock waves. Lancet, 1980, 2 : 1265-1268.

25. SAUERBRUCH T., HOLL J., SACKMANN M., WERNER R., WOTZKA R., PAUMGARTNER G. Disintegration of a pancreatic duct stone with extracorporeal shock waves in a patient with chronic pancreatitis. Endoscopy, 1987, $19:$ 207-208.

26. CHOI K. S., KIM M. H. Extracorporeal shock wave lithotripsy for the treatment of pancreatic duct stones. J. Hepatobiliary Pancreat. Surg., 2006 , $13: 86-93$.

27. AUGE B. K., PREMINGER G. M. Update on shock wave lithotripsy technology. Curr. Opin. Urol., 2002, $12: 287-290$.

28. PATEL S., GOMEZ V. Combined extracorporeal shockwave lithotripsy and ERCP for chronic calcific pancreatitis with the patient under general anesthesia in one session: an introduction to extracorporeal shockwave lithotripsy and a case example. VideoGIE., 2020, 5 : 513-516.

29. TANDAN M., REDDY D. N. Extracorporeal shock wave lithotripsy for pancreatic and large common bile duct stones. World J. Gastroenterol., 2011, $17: 4365-4371$

30. LI K., LIN T., ZHANG C., FAN X., XU K., BI L. et al. Optimal frequency of shock wave lithotripsy in urolithiasis treatment: a systematic review and meta-analysis of randomized controlled trials. J. Urol., 2013, 190 : 12601267.

31. KORPELA T., UDD M., TENCA A., LINDSTRÖM O., HALTTUNEN J., MYRSKYSALO S. et al. Long-term results of combined ESWL and ERCP treatment of chronic calcific pancreatitis. Scand. J. Gastroenterol., 2016, 51 : 866-871.

32. TANDAN M., REDDY D. N., SANTOSH D., VINOD K., RAMCHANDANI M., RAJESH G. et al. Extracorporeal shock wave lithotripsy and endotherapy for pancreatic calculi-a large single center experience. Indian $J$. Gastroenterol., 2010, 29 : 143-148.

33. DUMONCEAU J. M., COSTAMAGNA G., TRINGALI A., VAHEDI K., DELHAYE M., HITTELET A. et al. Treatment for painful calcified chronic pancreatitis: extracorporeal shock wave lithotripsy versus endoscopic treatment: a randomised controlled trial. Gut, 2007, $56: 545-552$.

34. KARASAWA Y., KAWA S., AOKI Y., OCHI Y., UNNO H., KIYOSAWA K. et al. Extracorporeal shock wave lithotripsy of pancreatic duct stones and patient factors related to stone disintegration. J. Gastroenterol., 2002, 37 : 369-375.

35. LI B. R., LIAO Z., DU T. T., YE B., CHEN H., JI J. T. et al. Extracorporeal shock wave lithotripsy is a safe and effective treatment for pancreatic stones coexisting with pancreatic pseudocysts. Gastrointest. Endosc., 2016, 84 : 6978.

36. DELHAYE M., ARVANITAKIS M., VERSET G., CREMER M., DEVIÈRE J. Long-term clinical outcome after endoscopic pancreatic ductal drainage for patients with painful chronic pancreatitis. Clin. Gastroenterol. Hepatol., 2004, 2 : 1096-1106
37. TADENUMA H., ISHIHARA T., YAMAGUCHI T., TSUCHIYA S., KOBAYASHI A., NAKAMURA K. et al. Long-term results of extracorporeal shockwave lithotripsy and endoscopic therapy for pancreatic stones. Clin. Gastroenterol. Hepatol., 2005, 3 : 1128-1135.

38. JABEN I. L., COTE G. A., FORSTER E., MORAN R. A., BROUSSARD K. A., SCOTT N. et al. Comparison of Urologist- vs GastroenterologistDirected Extracorporeal Shock Wave Lithotripsy for Pancreaticolithiasis. Clin. Gastroenterol. Hepatol., 2020.

39. DARISETTY S., TANDAN M., REDDY D. N., KOTLA R., GUPTA R., RAMCHANDANI M. et al. Epidural anesthesia is effective for extracorporeal shock wave lithotripsy of pancreatic and biliary calculi. World J. Gastrointest. Surg., 2010, 2 : 165-168.

40. ONG W. C., TANDAN M., REDDY V., RAO G. V., REDDY N. Multiple main pancreatic duct stones in tropical pancreatitis: safe clearance with extracorporeal shockwave lithotripsy. J. Gastroenterol. Hepatol., 2006, 21 : 1514-1518.

41. MOOLE H., JAEGER A., BECHTOLD M. L., FORCIONE D., TANEJA D., PULI S. R. Success of Extracorporeal Shock Wave Lithotripsy in Chronic Calcific Pancreatitis Management: A Meta-Analysis and Systematic Review. Pancreas, 2016, 45 : 651-658.

42. GUDA N. M., PARTINGTON S., FREEMAN M. L. Extracorporeal shock wave lithotripsy in the management of chronic calcific pancreatitis: a metaanalysis. Jop., 2005, $6: 6-12$.

43. VAN HUIJGEVOORT N. C. M., VELD J. V., FOCKENS P., BESSELINK M. G., BOERMEESTER M. A., ARVANITAKIS M. et al. Success of extracorporeal shock wave lithotripsy and ERCP in symptomatic pancreatic duct stones: a systematic review and meta-analysis. Endosc. Int. Open, 2020, 8: E1070-e1085.

44. SEVEN G., SCHREINER M. A., ROSS A. S., LIN O. S., GLUCK M., GAN S. I. et al. Long-term outcomes associated with pancreatic extracorporeal shock wave lithotripsy for chronic calcific pancreatitis. Gastrointest. Endosc., 2012, 75 : 997-1004.e1001.

45. CHOI E. K., MCHENRY L., WATKINS J. L., SHERMAN S., FOGEL E. L., COTÉ G. A. et al. Use of intravenous secretin during extracorporeal shock wave lithotripsy to facilitate endoscopic clearance of pancreatic duct stones. Pancreatology, 2012, $12:$ 272-275.

46. LI B. R., LIAO Z., DU T. T., YE B., ZOU W. B., CHEN H. et al. Risk factors for complications of pancreatic extracorporeal shock wave lithotripsy. Endoscopy, 2014, 46 : 1092-1100.

47. LAWRENCE C., SIDDIQI M. F., HAMILTON J. N., KEANE T. E., ROMAGNUOLO J., HAWES R. H. et al. Chronic calcific pancreatitis: combination ERCP and extracorporeal shock wave lithotripsy for pancreatic duct stones. South. Med. J., 2010, 103 : 505-508.

48. MILOVIC V., WEHRMANN T., DIETRICH C. F., BAILEY A. A., CASPARY W. F., BRADEN B. Extracorporeal shock wave lithotripsy with a transportable mini-lithotripter and subsequent endoscopic treatment improves clinical outcome in obstructive calcific chronic pancreatitis. Gastrointest. Endosc., 2011, 74 : 1294-1299.

49. TANDAN M., NAGESHWAR REDDY D., TALUKDAR R., VINOD K., KIRAN S., SANTOSH D. et al. ESWL for large pancreatic calculi: Report of over 5000 patients. Pancreatology, 2019, 19 : 916-921.

50. BRAND B., KAHL M., SIDHU S., NAM V. C., SRIRAM P. V., JAECKLE S et al. Prospective evaluation of morphology, function, and quality of life after extracorporeal shockwave lithotripsy and endoscopic treatment of chronic calcific pancreatitis. Am. J. Gastroenterol., 2000, 95 : 3428-3438.

51. INUI K., TAZUMA S., YAMAGUCHI T., OHARA H., TSUJI T., MIYAGAWA H. et al. Treatment of pancreatic stones with extracorporeal shock wave lithotripsy: results of a multicenter survey. Pancreas, 2005, 30 : 26-30.

52. SUZUKI Y., SUGIYAMA M., INUI K., IGARASHI Y., OHARA H., TAZUMA S. et al. Management for pancreatolithiasis: a Japanese multicenter study. Pancreas, 2013, $42: 584-588$.

53. OHARA H., HOSHINO M., HAYAKAWA T., KAMIYA Y., MIYAJI M., TAKEUCHI T. et al. Single application extracorporeal shock wave lithotripsy is the first choice for patients with pancreatic duct stones. Am. J. Gastroenterol., 1996, 91 : 1388-1394.

54. VAYSSE T., BOYTCHEV I., ANTONI G., CROIX D. S., CHOURY A. D., LAURENT V. et al. Efficacy and safety of extracorporeal shock wave lithotripsy for chronic pancreatitis. Scand. J. Gastroenterol., 2016, 51 : 13801385 .

55. RÖSCH T., DANIEL S., SCHOLZ M., HUIBREGTSE K., SMITS M., SCHNEIDER T. et al. Endoscopic treatment of chronic pancreatitis: a multicenter study of 1000 patients with long-term follow-up. Endoscopy, 2002, 34 : 765-771.

56. ETIK D. O., PARLAK E., OGUZ D., OZTAS E., KACAR S., ONDER F. O. et al. On demand pancreatic stenting in chronic pancreatitis might provide good palliation of pain. Acta Gastroenterol. Belg., 2019, 82 : 401-406. 
57. MERRILL J. T., MULLADY D. K., EARLY D. S., AZAR R. R., EDMUNDOWICZ S. A., JONNALAGADDA S. S. Timing of endoscopy after extracorporeal shock wave lithotripsy for chronic pancreatitis. Pancreas, 2011, $40:$ 1087-1090
58. BEYNA T., NEUHAUS H., GERGES C. Endoscopic treatment of pancreatic duct stones under direct vision: Revolution or resignation? Systematic review. Dig. Endosc., 2018, 30 : 29-37. 